\title{
Lead isotope analyses of leached feldspars: Constraints on the early crustal history of the Grenville Orogen
}

\author{
CHARles P. DeWOlF ${ }^{1,2}$ and Klaus MEZGER ${ }^{2 * *}$ \\ ${ }^{1}$ Department of Geological Sciences, University of Michigan, Ann Arbor, MI 48109-1063, USA \\ ${ }^{2}$ Max-Planck-Institut für Chemie, Postfach 3060, D-55020 Mainz, Germany
}

(Received September 11, 1993; accepted in revised form June 11, 1994)

\begin{abstract}
Lead isotopic data on leached K-feldspars, plagioclases, and muscovite provide constraints on the premetamorphic evolution of the Grenville Orogen in Ontario and New York. A boundary between reworked Archean crust to the northwest and new mantle-derived crust generated during mid-Proterozoic times to the southeast is identified within the northern portion of the Gneiss Belt of Ontario. The identification of juvenile mid-Proterozoic crust at the southeastern margin of the Orogen is consistent with previous investigations based on neodymium model ages. However, near the Grenville Front lead isotopes indicate the presence of reworked Archean crust rather than primary early Proterozoic crust postulated on the basis of neodymium model ages. This discrepancy between the lead and neodymium "isotopic terranes" underscores the necessity of using a multidisciplinary approach to identify possible terrane boundaries. Only through a combination of the lead with neodymium isotopes is it possible to distinguish between crust that formed during a single major orogenic cycle and crust that represents a mixture of old with new mantle-derived material. The combined neodymium and lead data imply that the Grenville Orogen in Ontario consists essentially of reworked Archean crust and juvenile mantle derived material generated around $1.5 \mathrm{Ga}$. The Grenville Orogen involved Archean crust that was depleted in thorium and uranium several hundred $\mathrm{Ma}$ before high grade metamorphism at $c a .1 .1 \mathrm{Ga}$. Such a depletion may have a significant impact on the geotherm achieved during orogeny and may explain the lower metamorphic thermal gradients observed for the Gneiss Belt.
\end{abstract}

\section{INTRODUCTION}

ISOTOPIC STUDIES HAVE become a major component in the interpretation of orogenic processes. Such studies are particularly important in old orogens, where isotopes provide the only absolute age and rate constraints on orogenic dynamics (e.g., Christensen et al., 1989; MEZGer et al., 1989; BurTON and O'Nions, 1991). In addition, isotopic studies (especially lead and neodymium) of ancient mountain belts provide time dependent information that is essential for the understanding of crustal genesis and evolution (DOE, 1967; MOORBATH et al., 1969; ZARTMAN, 1974; NELSON and DEPAOlo, 1985; DePaOlo, 1987; WoOden and Mueller, 1987) and of terrane amalgamation (MILISENDA et al., 1988; AYUSO and BEvIER, 1991; LIEW et al., 1991) that accompany orogenesis. Of major importance is the estimation of the amount of newly generated material added to the crust during an orogenic cycle and its distinction from old reworked material using radiogenic isotopes (e.g., PATCHETT, 1992). This distinction is essential for the delineation of terrane boundaries in high grade rocks (e.g., MILISENDA et al., 1988), In terms of crustal genesis, young orogenic belts, typically, cxhibit accreted juvenile magmatic arcs and exotic terranes and show reworked old crust extending considerably inboard into the existing craton. The deeply eroded mid-Proterozoic Grenville Orogen provides an opportunity to investigate the assembly of an ancient mountain belt and to test whether the observed processes of recent crust production and orogenesis were operative in Proterozoic time.

\footnotetext{
* Author to whom correspondence should be addressed.
}

The Grenville Orogen affords a unique opportunity to investigate the composition and evolution of the deep crust during orogenesis. The rocks of the Gneiss Belt of the Grenville Orogen (Fig. 1) experienced peak metamorphism at a depth of 35-45 km during orogeny (ANOVITZ and ESSENE, 1990). Because this crust has experienced pressure and temperature conditions prevailing at the crust-mantle boundary of average continental crust, analysis of the exposed Grenville Orogen can yield insights into how lower crustal processes work during orogenesis.

A large dataset with neodymium model ages has been published for the Grenville Orogen and was used for a tectonic reconstruction of parts of this large orogenic belt (e.g., DICKIN and MCNUTT, 1989. 1990; DICKIN et al., 1990). For a robust interpretation of the Nd-model ages it is essential to be aware of the possible geologic meaning of these model ages (e.g., ARNDT and GOLDSTEIN, 1987). A basic assumption in using such model ages is that they represent the last time that the element under consideration (in this case, neodymium ) was in isotopic equilibrium with some model reservoir, assuming a single stage closed system evolution since that time. Thus, using the present-day ${ }^{143} \mathrm{Nd} /{ }^{144} \mathrm{Nd}$ and ${ }^{147} \mathrm{Sm} /{ }^{144} \mathrm{Nd}$ of a sample, one can calculate the last time it may have been in equilibrium with a reservoir such as the model depleted mantle (DEPAOLO, 1987). This model age $\left(T_{\mathrm{DM}}\right)$ provides one piece of evidence for the average time of crustal residence of neodymium within the sample. The implicit assumptions are that the last major fractionation of the $\mathrm{Sm} / \mathrm{Nd}$ ratio was that associated with crust formation, and that neodymium has not been exchanged with reservoirs with a different $\mathrm{Sm} /$ $\mathrm{Nd}$ or age. Because clastic sediments, granitic rocks, and 


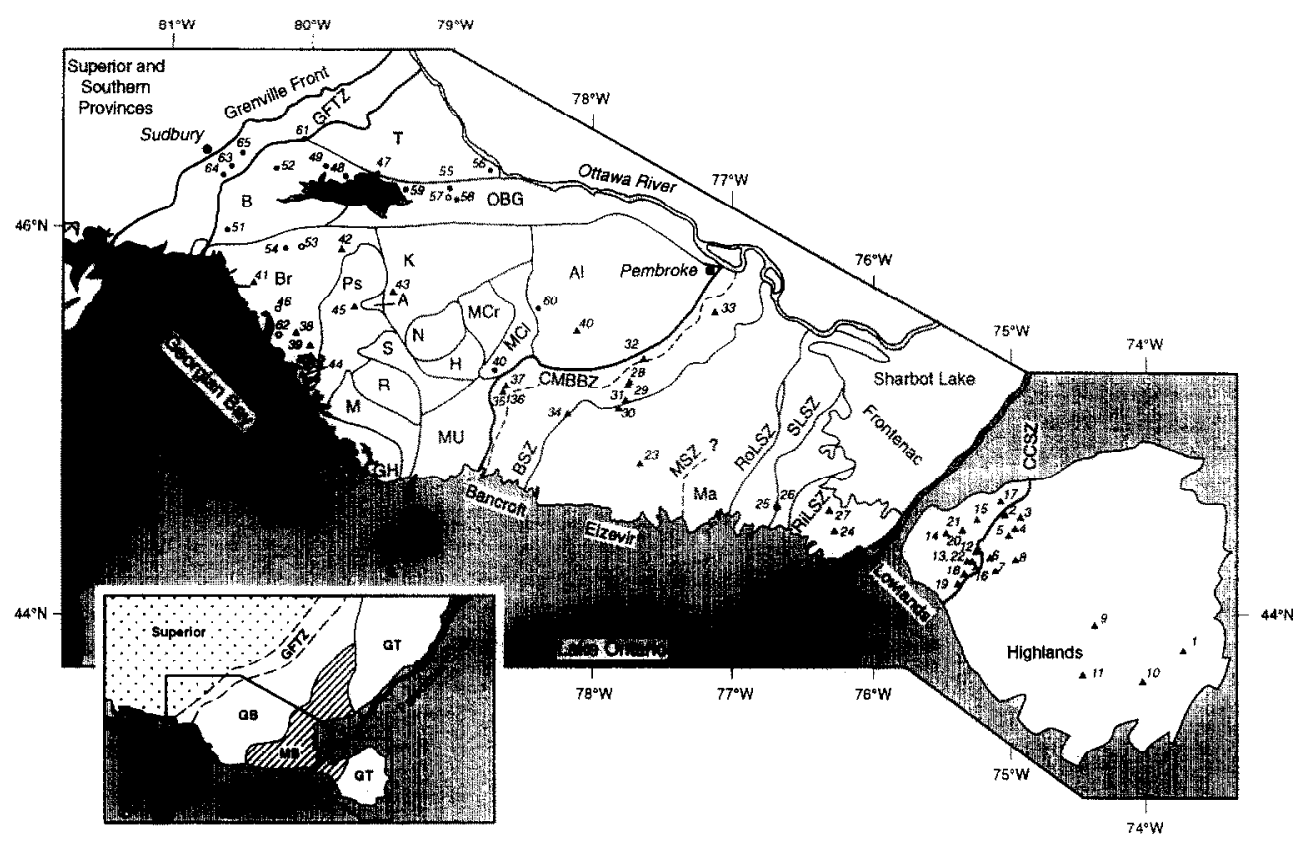

FiG. 1. Map of the Ontario Grenville Orogen and Adirondack Lowlands and Highlands of New York State showing sample locations (modified from MEzGER et al.. 1993). Filled circles = Northern Grenville Array (NGA), filled triangles $=$ Southern Grenville Array $(\mathrm{SGA})$, open circles = boundary zone, see text for details. Abbreviations: GB $=$ Gneiss Belt, $M B=$ Metasedimentary Belt, $G T=$ Granulite Terrane; $\operatorname{CCSZ}=$ Carthage-Colton shear zone, RiLSZ - Rideau Lake shear zone, SLSZ = Sharbot Lake shear zone, RoLSZ = Robertson Lake shear zone, MSZ = Moorton shear zone, BSZ = Bancroft Shear zone, $\mathrm{MBBZ}=$ Metasedimentary Belt Boundary Zone, GFTZ = Grenville Front Tectonic Zone, $\mathrm{T}=$ Tomiko domain, $\mathrm{B}=$ Burwash domain, $\mathrm{Br}=$ Britt domain, $\mathrm{OBG}=$ Ottawa-Bonnechere Graben. $\mathrm{PS}=$ Parry Sound domain, $\mathrm{K}=$ Kiosk subdomain, $\mathrm{A}=$ Ahmic subdomain, $\mathrm{S}=$ Sequin subdomain, $\mathrm{R}=\mathrm{Rosseau}$ subdomain, $\mathrm{M}=$ Moon River subdomain, $\mathrm{GH}=$ Go Home subdomain, $\mathrm{Mu}=$ Muskoka domain, $\mathrm{A}=$ Algonquin domain, $\mathrm{MCr}=\mathrm{McCraney}$ subdomain, $\mathrm{MCl}=$ McClintock subdomain. $\mathrm{N}=$ Novar subdomain, $\mathrm{H}=$ Huntsville subdomain. Sample locations available upon request.

many granulite facies gneisses have similar $\mathrm{Sm} / \mathrm{Nd}$, and this ratio is very distinct from the $\mathrm{Sm} / \mathrm{Nd}$ of the mantle, many workers have used the ( $\left.T_{D M}\right)$ ages of crustal rocks to estimate their average "crustal residence age" (e.g., DEPAOLO, 1987; ARNDT and GOLDSTEIN, 1987; PATCHETT, 1992). However. $\mathrm{Sm} / \mathrm{Nd}$ can be altered by crustal processes such as partial melting, metamorphism, weathering, and diagenesis (e.g., ARNDT and GOLDSTEIN, 1987; GRAUCH, 1989; AWWILER and MACK, 1991; OHR et al., 1994). An additional complication is that neodymium model ages may reflect mixing of crust of two different ages. In such cases, the single decay $\mathrm{Sm} / \mathrm{Nd}$ system provides no unique constraint on either the timing or extent of mixing. In order to evaluate the significance of the neodymium model ages for the Grenville Orogen (DICKIN and MCNUTT, 1989, 1990; DICKIN ct al., 1990). we present sixty-five analyses of lead isotopes from leached feldspars and one muscovite from a range of rock types geographically distributed throughout the Grenville Orogen of southwestern Ontario and the contiguous Adirondack Mountains of New York State (Fig. 1). This dataset provides a useful context for a review of models for lead behavior during orogenesis and high grade metamorphism (e.g., ZARTMAN and DOE, 1981).

Comparison of the lead with published neodymium data allows evaluation of the different information provided by the lead and neodymium systems and yields better constraints on the premetamorphic crustal history of the Grenville Oro- gen. The two systems show quite distinct behavior under various geologic conditions. The U-Pb system contrasts with the Sm-Nd system in three important ways. First, the fractionation of uranium from lead during crustal generation is. typically, small. For this reason, models of lead isotope evolution (e.g., ZARTMAN and DOE, 1981) show only a small degree of dispersion in isotopic composition of different crustal and mantle reservoirs through time. Second, the U/ $\mathrm{Pb}$ system is much more sensitive to processes within the crust and can be significantly modified by high-grade metamorphism and weathering. This sensitivity means that the lead isotopic system may preserve a record of crustal history (e.g., WOODEN et al., 1988). The lower crust typically shows a large depletion in uranium, resulting in low $U / P b$ and high $\mathrm{Th} / \mathrm{U}$. This depletion has long been associated with granulite facies metamorphism (e.g., DOE, 1967; HEIER, 1973; RUDNICK et al., 1985), but in some cases, may not be restricted just to high-grade metamorphism and may occur also under amphibolite facies conditions. Third, the most important difference between the U-Pb and $\mathrm{Sm}-\mathrm{Nd}$ systems is that the paired uranium decay schemes, ${ }^{238} \mathrm{U}_{-}{ }^{206} \mathrm{~Pb}$ and ${ }^{235} \mathrm{U}^{207} \mathrm{~Pb}$, with substantially different decay constants, allow constraints to be placed on the timing of any process that modifies $U /$ $\mathrm{Pb}$ ratios.

A substantial amount of strontium isotope data is also available from the Grenville Orogen (e.g., KROGH and HURI.IY, 1968; HEAMAN et al., 1982; MARCANTONIO et al., 1990); 
however, the interpretation of this data in the same context as the lead and neodymium data is hampered by the large changes possible in the $\mathrm{Rb} / \mathrm{Sr}$ of crustal rocks as a result of magmatic, metamorphic, and sedimentary processes. Due to these changes as a result of the complex history of the Grenville Orogen, it is exceedingly difficult to obtain unambiguous initial strontium isotope ratios for these metamorphic rocks. Therefore, the strontium data are not treated in this discussion.

Because feldspars strongly prefer lead over uranium, the lead isotopic compositions of leached feldspars provide good estimates for the lead isotope compositions of the host rocks at the time of last equilibration (e.g., LUDWIG and SILVER, 1977; GARIÉPY and ALLÈGRE, 1985; HouSH et al., 1989; CHAMBERLAIN and BowrING, 1990). This time may represent the time of igneous crystallization or the time of cessation of lead diffusion and exchange in a slowly conled metamorphic system. The feldspars record the time integrated ${ }^{238} \mathrm{U} /{ }^{204} \mathrm{~Pb}(\mu)$ of the lead in the rock, up until the time of last equilibration. K-feldspar occurs in a wide range of crustal rock types and has an advantage over plagioclase, because the larger ionic radius of potassium allows greater substitution of lead, while discriminating against uranium. In this study, we have also used plagioclase and muscovite in rocks where $\mathrm{K}$-feldspar was not present. In each case, care was taken to avoid the incorporation of tiny inclusions of radioactive phases, which are particularly abundant in micas.

\section{GEOLOGIC SETTING}

The Grenville Orogen forms the southeast margin of the Canadian Precambrian Shield and consists of a lincar belt, the cxposed portion of which is 1900 by $400 \mathrm{~km}$, extending from the Atlantic Ocean to Lake Huron, and includes the Adirondack Mountains, exposed just to the southeast in New York State. The Grenville Orogen represents a major segment of the North American continent, with Grenville equivalent rocks forming the cores of Phanerozoic uplifts in the Appalachians, Llano Uplift, Ouachita Mountains, and Oaxaca Complex of Mexico. The exposed Grenville of Ontario and New York has been the subject of years of detailed field, petrologic and isotopic study (e.g., BuDDINGTON, 1939; ENGEL and ENGEL, 1953; DOE, 1962; DEWEY and BURKE, 1973; DAVIDSON et al., 1982; HANMER, 1988; MEZGER et al., 1991a,b) and is considered to represent the exposed root of a $c a .1 .1 \mathrm{Ga}$ old orogenic belt.

Based on structure, lithology, and detailed thermochronology, the Grenville Orogen can be divided into the Gneiss Belt, Metasedimentary Belt, and Granulite Terrane (Fig. 1). These three major terranes are separated by large-scale shear zones: the Metasedimentary Belt Boundary Zone separating the Gneiss Belt from the Metasedimentary Belt, and the Carthage-Colton shear zone separating the Metasedimentary Belt from the Granulite Terrane (Adirondack Highlands). The Gneiss Belt is separated from the Superior Province to the North by the Grenville Front Tectonic Zone (Fig. 1). These shear zones have been interpreted as major terrane boundaries and may be traced seismically in the subsurface beneath the Paleozoic cover in the eastern United States (CULOTTA et al., 1990). The salient features of each of these composite terranes is discussed below.

\section{Gneiss Belt}

The Gneiss Belt is characterized by layered felsic gneisses and amphibolites metamorphosed in the upper amphibolite to granulite facies. It contains a number of ductile shear zones that separate domains and subdomains with distinct lithotectonic characteristics (DAVIDSON, 1984). These shear zones contain rotated porphyroclasts and stretching lineations that indicate low angle ductile thrusting toward the northwest (DAVIDSON, 1986). The domains have been interpreted to represent a series of imbricate crustal slices assembled during orogenesis (CUlSHAw et al., 1983; DavidSON, 1984). DICKIN et al. (1990) suggested that the Gneiss Belt may be divided into three sections based on neodymium model ages only. As yet, this division does not correspond with any observed structural boundaries. Radiometric dating provides evidence for an extended crustal history in the Gneiss Belt. Inferred igneous crystallization ages range from 1.8 to $1.18 \mathrm{Ga}$ (KROGH and DAVIS, 1972; VAN BREEMEN and DA. VIDSON, 1988; CORRIGAN, 1990; VAN BREEMEN and DAVIDSON, 1990). TUCCILLo et al. (1992) reported evidence for high grade regional metamorphism at $1.4 \mathrm{Ga}$. The timing of the onset of synmetamorphic thrusting in the Gneiss Belt has been estimated at 1.16$1.12 \mathrm{Ga}$ (VAN BREEMEN and HANMER, 1986; TUCCILLO et al., 1992).

\section{Metasedimentary Belt}

The Metasedimentary Belt consists largely of sedimentary and volcanic rocks that have experienced metamorphic conditions ranging from greenschist to granulite facies. The Metasedimentary Belt is subdivided into the Bancroft, Elzevir, Sharbot Lake, and Frontenac Domains and the Adirondack Lowlands, each separated by major shear zones. The earliest known magmatism in the Canadian part of the Metasedimentary Belt occurred at ca. $1.37 \mathrm{Ga}$ (LuMBERS et al., 1991), with a number of igneous suites having been identified with ages ranging from 1.37 to $1.04 \mathrm{Ga}$ (LumBERs et al., 1991). In the Adirondack Lowlands, the earliest evidence for magmatism is at ca 1.42 Ga (MCLELLAND et al., 1988) with the onset of high grade metamorphism at ca. l.16 Ga (MEZGER et al., 1991a).

\section{Granulite Terrane}

The Granulite Terrane is the most easterly exposed domain and consists of the Adirondack Highlands. Here, the dominant rock types are meta-igneous gneisses, including large anorthosite massifs. The evidence for oldest magmatism is provided by $c a .1 .32 \mathrm{Ga}$ old zircons from a tonalitic gneiss (MCLELLAND et al., 1988). Emplacement of the anorthosite massifs most likely accompanied or predated the onset of granulite facies metamorphism at ca. $1.15 \mathrm{Ga}$ (MCLELLAND et al., 1988), high-grade metamorphism, then continued either continuously or episodically for $c a$. $150 \mathrm{Ma}$ (MEZGER et al., 199la).

\section{METHODS}

One purpose of this study was to evaluate the lead isotope characteristics of the different terranes of the Grenville Orogen; therefore, a variety of rock types were sampled with emphasis on samples where other thermobarometric and geochronologic information were available. Many of these samples were the subject of previous petrological and geochronological studies (ANOVITZ and ESSENE, 1990: MEZGER et al. 1991a; Tuccillo et al., 1992).

About 10-20 mg of handpicked K-feldspar, plagioclase, or muscovite separates ( $40-80$ mesh, depending on the presence of inclusions and alteration) were leached sequentially in $\mathrm{HCl}-\mathrm{HNO}_{3}(>6 \mathrm{~h})$ and $10-20 \% \mathrm{HF}$ (30 min), prior to dissolution in HF. This leaching was done in an attempt to dissolve any fine grained alteration phases in microfractures and to remove acid soluble lead adsorbed on the surface of feldspar grains. Leaching may also remove radiogenic lead from the decay of uranium and thorium incorporated into the feldspar during its growth (LUDWIG and SILVER, 1977). Due to recoil, this lead is, likely, not in crystallographic sites, as it is expected for the common lead incorporated during feldspar growth or later equilibration. This leaching technique has been shown to preserve the isotopically most primitive lead from feldspars (e.g. LUDWIG and Sil VER, 1977; GARIEPY and ALLÉrRE, 1985; Housh et al, 1989; Chamberlain and Bowring, 1990). After dissolution in HF, samples were dried down on a hot plate under a flow of clean air and redissolved in $2 \mathrm{~N} \mathrm{HCl}$. The lead was separated, using a moditication of the $\mathrm{HBr}$ method on $\mathrm{AG} 1 \times 8$ anion exchange resin. Sample filament loads were estimated at 100-200 ng; procedural blanks were 30-200 pg. Most lead isotopic compositions were measured by static analysis on a VG Sector thermal ionization mass spectrometer at the University of Michigan fitted with six Faraday collectors. Some analyses were performed using the NBS Shields type mass spectrometer 
TABLE 1: Pb Isotopic Compositions of K-Feldspars

SAMPLE $\quad{ }^{206 \mathrm{pb} / 204 \mathrm{~Pb}} \quad{ }^{207} \mathrm{~Pb} / 204 \mathrm{~Pb} \quad{ }^{208} \mathrm{~Pb} / 204 \mathrm{~Pb} \quad$ LITHOLOGY

GNEISS TERRANE

Adirondack Highlands

86-8a

$90-4 \quad 17.338$

90-50/1 (plag) $\quad 17.538$

90-50 (plag) $\quad 17.613$

$90.60 \quad 22.341$

$90-64 \quad 17.423$

$90-65$ (plag) $\quad 17.474$

90-67 plag $\quad 17.551$

BM1-F $\quad 17573$

GR1 $\quad 17.656$

SP-1b $\quad 17.167$

METASEDIMENTARY.BELT

Adirondack Lowlands

AD 161B

ED.161B

17.746

64A $\quad 16.967$

$87 \mathrm{C} \quad 16.982$

$86-\mathrm{S} \quad 17.360$

$90-49 \quad 17.132$

ED $-99 \quad 17.363$

HA.369 $\quad 17.985$

L.B-81 $\quad 16.814$

$86-6 \quad 17.997$

$87 \mathrm{~F} \quad 16.995$

MIGMATTIE $\quad 17.038$

Fronienac and Elevir Domain

$\begin{array}{llll}89-3 \text { (plag) } & 17.465 & 15.490 & 36.878 \\ 89-24 \text { (plag) } & 17.372 & 15.445 & 37.063 \\ 90-79 \text { (plag) } & 17.067 & 15.369 & 36.298 \\ 90-792 \text { (plag) } & 17.052 & 15.434 & 36.447 \\ \text { fa86-3 (plag) } & 16.885 & 15.386 & 36.382\end{array}$

$15.446 \quad 36.747$

$15.438 \quad 36.467$

$\lcm{15.389 \quad 36.363}$

$15.443 \quad 36.821$

$15.428 \quad 36.461$

$15.492 \quad 36.578$

$15.526 \quad 38.557$

$15.388 \quad 36.296$

$15.515 \quad 36.724$

$15.408 \quad 36.389$

$15.443 \quad 36.426$

Bancroft Domain

Bancroft

89-18

17.239

$89.18 \quad 17.701$

$89.5 \quad 17.094$

$89.6 \quad 17.039$

diane $\quad 16.887$

REN 16.905

$\mathrm{xx}$

16.905
17.407

15.415

15.485

15.381

15.406

15.382

15.397

15.431

36.846
37.081
36.264
36.514
36.541
36.459
36.814

Metasedimentary Belt Boundary Zone

$\begin{array}{llll}90.88 \mathrm{~b} / 2 & 17.168 & 15.369 & 36.339 \\ 90.88 \mathrm{~b} / 1 & 17.314 & 15.357 & 36.282 \\ 90.89 & 16.790 & 15.371 & 36.275 \\ & & & \\ \text { GNEISS BELT } & & & \\ 91.15 \mathrm{C} & 16.979 & 15.422 & 36.558 \\ 91-16 & 17.102 & 15.433 & 36.651 \\ \text { ALG 83C 1 (plag) } & 17.044 & 15.447 & 36.616 \\ \text { GRU 83C 17 } & 16.975 & 15.422 & 36.374 \\ \text { GRU 83C 4 } & 17.354 & 15.476 & 36.641 \\ \text { LNT 83C 2 } & 17.484 & 15.485 & 36.722 \\ \text { PS1 (msc) } & 17.391 & 15.462 & 36.737 \\ \text { 5sa (plag) } & 17.308 & 15.442 & 36.822 \\ 91-14 & 16.409 & 15.356 & 36.299 \\ 91.5 \mathrm{a} & 15.976 & 15.239 & 35.959 \\ 91.6 \text { (plag) } & 15.070 & 15.037 & 35.061 \\ 91.7 \mathrm{a} & 15.895 & 15.145 & 35.399 \\ \text { ALG 83C 20 } & 16.140 & 15.309 & 35.192 \\ \text { BUR83C 3 } & 15.852 & 15.284 & 35.711\end{array}$

MARBLE
CALCSIIICATE
AMPHIBOLITE
AMPHIBOLITE
GRANITE
GRANITE
GRANITE
GRANTTE
PELITE
FAY-GRANTTE
PELITE

$\begin{array}{rr}\text { PELITE } & a \\ \text { GRANITE } & \\ \text { MARBLE } & a \\ \text { MARBLE } & a \\ \text { CALC-SILICATE } & \\ \text { PELITE } & a \\ \text { PELTTE } & a \\ \text { PELITE } & a \\ \text { MARBLE } & \\ \text { MARBIE } & \\ \text { PELITE } & \end{array}$

CALC-SILICATE

CALC-SILICATE

MARBLE

MARBLE

AMPHIBOLITE

PEGMATITE

PEGMATITE

SYENTEE

SKARN

SYENITE

PELTE

PEGMATITE

GRANITE

GRANTTE

GRANITE

$\begin{aligned} \text { PEGMATITE } & \mathrm{S} \\ \text { GRANITE } & \mathrm{S} \\ \text { AMPHIBOLITE } & \mathrm{S} \\ \text { PELITE } & \mathrm{S} \\ \text { QF GNEISS } & \mathrm{S} \\ \text { GRANITE } & \mathrm{S} \\ \text { PELITE } & \mathrm{S} \\ \text { AMPHIBOLITE } & \mathrm{S} \\ \text { PEGMATITE } & \mathrm{N} * \\ \text { PEGMATITE } & \mathrm{N} \\ \text { GRANITE } & \mathrm{N} \\ \text { GRANITE } & \mathrm{N} \\ \text { PELITE } & \mathrm{N} * \\ \text { PELITE } & \mathrm{N}\end{aligned}$


TABLE 1 (CONT)

\begin{tabular}{|c|c|c|c|c|c|c|}
\hline \multicolumn{2}{|c|}{ SAMPLE } & \multirow{2}{*}{$\frac{206 \mathrm{~Pb} / 204 \mathrm{~Pb}}{14.961}$} & \multirow{2}{*}{$\frac{{ }^{207} \mathrm{~Pb} /{ }^{204} \mathrm{~Pb}}{14.934}$} & \multirow{2}{*}{$\frac{208 \mathrm{~Pb} / 204 \mathrm{pb}}{35.783}$} & \multicolumn{2}{|l|}{ LITHOLOGY } \\
\hline 52 & BUR83C 69 & & & & GRANITE & $\mathrm{N}$ \\
\hline 53 & GRU $83 C 10$ & 16.531 & 15.383 & 35.989 & QF GNEISS & $\mathrm{N} * *$ \\
\hline 54 & GRU $83 C 12$ & 16.386 & 15.380 & 36.387 & PELITE & $\mathrm{N}^{*}$ \\
\hline 55 & MAT $83 C 1$ & 14.689 & 15.079 & 34.611 & QF GNEISS & $N^{*}$ \\
\hline 56 & MAT $83 C 21$ & 14.985 & 15.046 & 35.584 & QF GNEISS & $N^{*}$ \\
\hline 57 & MAT $83 C 4$ & 16.579 & 15.409 & 36.142 & GRANITE & $N * *$ \\
\hline 58 & MAT83C 13 & 16.010 & 15.278 & 35.706 & PEI.ITE & $\mathrm{N} *$ \\
\hline 59 & NOB 16 & 16.802 & 15.476 & 36.639 & GRANITE & $\mathbf{N}^{*}$ \\
\hline 60 & rdt3 (plag) & 16.408 & 15.312 & 36.075 & AMPHIBOLITE & $\mathbf{N}$ \\
\hline 61 & RIV83Cl & 16.082 & 15.232 & 35.722 & GRANITE & $\mathbf{N}$ \\
\hline 62 & SH88-7b & 16.691 & 15.394 & 37.020 & PELTTE & $N * * b$ \\
\hline \multicolumn{7}{|c|}{ GRENVILLE FRONT TECTONIC ZONE } \\
\hline 63 & BUR 83 C 35 & 16.738 & 15.550 & 36.788 & QF GNEISS & $\mathbf{N}$ \\
\hline 64 & $91-10$ & 16.457 & 15.536 & 36.692 & GRANITE & $\mathbf{N}$ \\
\hline 65 & BUR44 & 18.830 & 15.852 & 37.906 & PELITE & $\mathbf{N}$ \\
\hline
\end{tabular}

\footnotetext{
Sample locations are given in Fig 1 . by sample number. All dala are corrected for fractionation $(0.09 \%$ per a.m.u.) based on analyses of NBS 981 . Measured NBS 981 ratios: ${ }^{207} \mathrm{~Pb} / 206 \mathrm{~Pb}=0.91381 \pm 0.05 \%(2 \sigma)$; ${ }^{206} \mathrm{~Pb} / 204 \mathrm{~Pb}=16.907 \pm .10 \%(2 \sigma), \mathrm{n}=35$. Minerals other than $\mathrm{K}$-feldspar are indicated in parentheses (plag = plagioclase; $m s c=$ muscovite) $S=$ Southem Grenville Array, $N=$ Northem Grenville Array.

a from Mezger et al., 1991

$\mathrm{b}$ from Tuccillo et al., 1992

+ Carthage-Colton Mylonite Zone

* Sample from south of suture inferred by Dickin and McNutt (1989)

** Sample plots at juntion of two arrays in Fig 2a. Most likely belongs to NGA (see text)
}

at SUNY Stony Brook with a single Faraday collector. Isotopic ratios were corrected for fractionation using repeated analyses of NBS 981 and NBS 982 (Tablc 1). Differences in measured fractionation between the two labs were negligible.

\section{RESULIS}

The lead isotope data are given in Table 1, listed by domain. In addition, the data are subdivided into two distinct arrays, based on an obvious break in lead isotopic signature that occurs approximately $180 \mathrm{~km}$ SE of the Grenville Front (Fig. 1). The data are displayed in Fig. 2, along with the model evolution curves of ZARTMAN and DOE (1981), reference Proterozoic geochrons, and secondary isochron slopes.

\section{Southern Grenville Array (SGA)}

Data from the southern Gneiss Belt, the Metasedimentary Belt, and the Granulite Terrane cluster in a remarkably tight array, hereafter referred to as the southern Grenville array or SGA (Fig. 2). These data are in general agreement with the few analyses of K-feldspars obtained in earlier studies by DOE (1962) and ZARTMAN and WASSERBURG (1969). No distinction can be made between these terranes on the basis of their lead isotopic composition. The SGA array (Fig. 2a) lies to the right of the $1.1 \mathrm{Ga}$ geochron and yields single-stage $\mu$ values of $7.8-8.5$ using Canon Diabolo troilite as starting point for $\mathrm{Pb}$-evolution and $4.55 \mathrm{Ga}$ for the age of the Earth. Single-stage model ages are younger than the expected time of closure of lead exchange in these feldspars shortly after the peak of Grenvillian metamorphism at ca. 1.1 Ga. This array also lies to the right of the model compositions for mantle and crustal reservoirs (ZARTMAN and DOE, 1981) at $1.1 \mathrm{Ga}$. The SGA array is elongate with the best fit slope of $0.12 \pm 0.02(\sigma)$ (MSWD $=13.5$ ). This slope is consistent with a small degree of initial isotopic variation and closed system evolution, beginning at $1.5 \mathrm{Ga}$ and lasting until the closure of feldspar to isotopic exchange, following the peak of metamorphism at $1.1 \mathrm{Ga}$ (Fig. 2). The range in second stage ${ }^{238} \mathrm{U} /{ }^{204} \mathrm{~Pb}(\mu)$ required to account for the observed spread is approximately 5-20. Variations in whole-rock $\mu$ of this magnitude in various crustal rock types are reasonable (e.g., WoOden et al., 1988).

The SGA could possibly be generated in three different ways: (1) by evolution of a juvenile mid-Proterozoic crustal component, and the formation of a secondary isochron from 1.5 to $1.1 \mathrm{Ga}$; (2) by large scale reworking of old crust, leading to a homogeneous mixture that then evolved from 1.5 to 1.1 $\mathrm{Ga}$, forming a secondary isochron, and (3) by mixing of a mantle derived component with older homogeneous crust on a regional scale at $1.1 \mathrm{Ga}$, with the resulting linear array having no age significance. Model (2) is initially attractive 

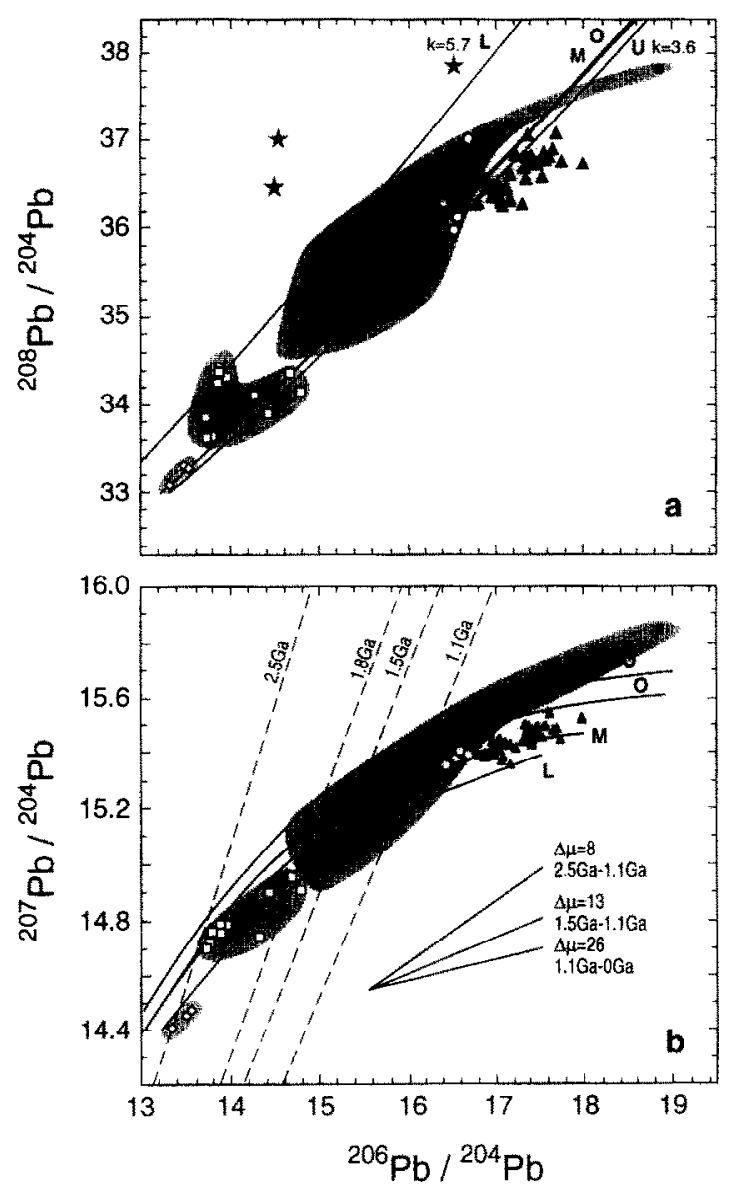

FlG. 2. Lead isotopic compositions of leached feldspars and one muscovite from the Grenville Orogen. The symbols are the same as in Fig. 1. Also shown for reference are feldspar data from the Superior Province (diamonds: GARIÉPY and ALLËGRE, 1985) and the Grenville Front region in Québec (open squares: GARIEPY et al, 1990), and only on the ${ }^{208} \mathrm{~Pb} /{ }^{204} \mathrm{~Pb}$ vs. ${ }^{206} \mathrm{~Pb} /{ }^{204} \mathrm{~Pb}$ diagram, whole-rock data from charnockites in the Grenville Front region in Québec (stars: GARIEPY et al. 1990). Curves represent the evolution of idealized upper crust (U), orogene (O), mantle (M), and lower crust (L) lead from the Plumbotectonics model (ZARTMAN and DOE, 1981). "Paleogeochrons" are shown in the ${ }^{207} \mathrm{~Pb} /{ }^{204} \mathrm{~Pb}$ vs. ${ }^{206} \mathrm{~Pb} /{ }^{204} \mathrm{~Pb}$ diagram for $2.5,1.8,1.5$, and I.I Ga. Also shown in the ${ }^{207} \mathrm{~Pb} /{ }^{204} \mathrm{~Pb} v \mathrm{~s} .{ }^{206} \mathrm{~Pb} /$ ${ }^{204} \mathrm{~Pb}$ diagram are representative slopes and $\Delta_{k}$ values for secondary isochrons resulting from closed system evolution for the time intervals $2.5-1.1 \mathrm{Ga}, 1.5-1.1 \mathrm{Ga}$, and $1.1 \mathrm{Ga}$ to the present. In the ${ }^{208} \mathrm{~Pb} /$ ${ }^{204} \mathrm{~Pb}$ vs. ${ }^{206} \mathrm{~Pb} /{ }^{204} \mathrm{~Pb}$ diagram, two reference ${ }^{232} \mathrm{Th} /{ }^{238} \mathrm{U}$ ( $\kappa$ values) are shown. The lead data for the SGA can be explained by closed system evolution from $1.5 \mathrm{Ga}$ to $1.1 \mathrm{Ga}$ and $1.3<\kappa<3.6$.

because the SGA abuts the center of the NGA, and the NGA is interpreted below to record the presence of older crust in the Gneiss Belt. However, models (2) and (3) are excluded, because they require contribution of a significant amount of old crust, which is inconsistent with neodymium model ages (MARCANTONIO et al., 1990; DALY and MCLELLAND, 1991) and with known zircon crystallization ages (MC LELLAND et al., 1988; MARCANTONIO et al., 1990), indicating largely juvenile crust in the Metasedimentary Belt and Granulite Terrane at $c a$. 1.4-1.5 Ga. In addition to being inconsistent with the neodymium model ages, isotopic homogenization of the crust on a $10^{4} \mathrm{~km}^{2}$ scale at $1.4-1.5 \mathrm{Ga}$ is considered unlikely.
The interpretation of the SGA representing a secondary isochron is supported by a comparison between the feldspar and galena data from the Metasedimentary Belt (Fig. 3; FLETCHER and FARQUHAR, 1982a). The galena deposits in this belt have been interpreted as being premetamorphic and possibly having a syn-sedimentary origin (FI.FTCHER and FARQUHAR. 1982a). The galena data are generally collinear with the feldspar data, but are displaced to less radiogenic values. This displacement is reasonable, because it is expected that the galenas, scavenging lead from a wide area, represent an approximate average composition of the Metasedimentary Belt at the time of mineralization ( $c$ a. $1.3 \mathrm{Ga}$ : LuMBERS et al., 1991). The slope and required $\mu$ (Fig. 3) necessary for the lead isotopic composition to evolve from the galena field to the feldspar field are consistent with evolution from 1.3 to $1.1 \mathrm{Ga}$ and reasonable crustal $\mu$ values $(<20)$. Galenas from Balmat in the Adirondack Lowlands have ${ }^{206} \mathrm{~Pb} /{ }^{214} \mathrm{~Pb}$ ratios (FLETCHER and FARQUHAR, 1982b), similar to those from the Metasedimentary Belt, but tend to have ${ }^{207} \mathrm{~Pb} /{ }^{204} \mathrm{~Pb}$ for a given ${ }^{206} \mathrm{~Pb} /{ }^{204} \mathrm{~Pb}$ (Fig. 3) at the high end of the $\mathrm{K}$-spar array, and with one sample significantly higher. These data may indicate the presence of older crust in the Adirondack Lowlands, or may have resulted from some isotope fractionation during analysis.

The observed maximum range of ${ }^{207} \mathrm{~Pb} /{ }^{204} \mathrm{~Pb}$ in young oceanic basalts (ocean islands and MORB) at a given ${ }^{206} \mathrm{~Pb}$ / ${ }^{204} \mathrm{~Pb}$ (hereafter referred to as "the width of the MORB field")
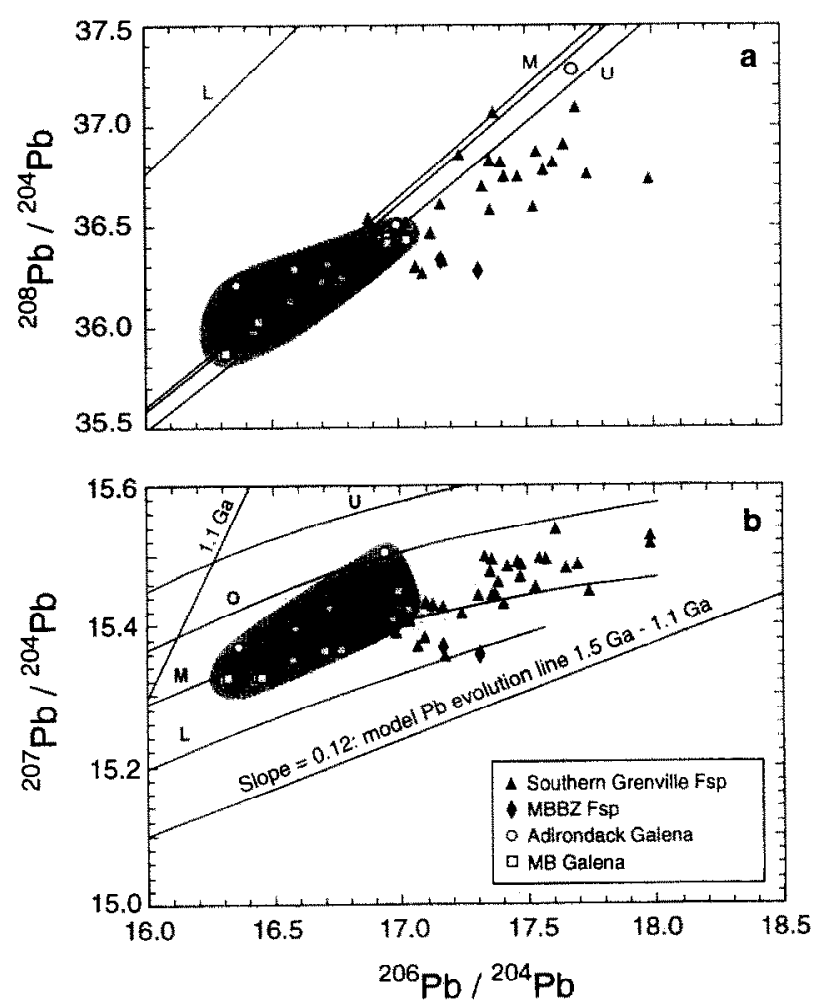

Fic. 3. Lead isotopic data from the southern Grenville Orogen with galena data from the Adirondacks (Balmat ores) and the Metasedimentary Belt (FLETCHER and FARQUHAR 1982a,b) for comparison. Included is also a feldspar from a shear zone, the Metasedimentary Belt Boundary Zone (Table 1). Growth curves as in Fig. 2. 
is approximately 0.1 (TILTON, 1983). If this width of the MORB field has not decreased through geologic time, any variation in our data exceeding 0.1 requires an older crustal component. The measured $\mathrm{Pb}$-isotope ratios of the feldspars lie within the "paleo-MORB" field as observed for galenas by FlETCHER and FARQUHAR (1982a,b) (Fig. 4). Given the large range of ${ }^{206} \mathrm{~Pb} /{ }^{204} \mathrm{~Pb}$ in modern $\mathrm{MORB}$, the relative position of the feldspars and galenas with respect to the MORB field is insensitive to small variations in $\mu$ used in the back-correction, or whether the field is back-corrected to 1.4 or $1.1 \mathrm{Ga}$. The coincidence of the feldspar and the MORB fields could be explained by an original source with an isotopic composition dominated by MORB-like material, and no dramatic accumulation of radiogenic lead during the $300 \mathrm{Ma}$ residence time in the crust.

Young oceanic sediments have higher ${ }^{207} \mathrm{~Pb} /{ }^{204} \mathrm{~Pb}$ than MORB. This difference results from the contribution of Archean or early Proterozoic crustal components into ocean sediments. Volcanic rocks from island arcs, that have sediments derived from old crust incorporated to their trenches, have been shown to have slightly elevated ${ }^{207} \mathrm{~Pb} /{ }^{204} \mathrm{~Pb}$ (J. P. DAVIDSON, 1986). Because the production of ${ }^{207} \mathrm{~Pb}$ is largely an Archean and early Proterozoic phenomenon, the degree of elevation of ${ }^{207} \mathrm{Ph} /{ }^{204} \mathrm{~Pb}$ expected if the southern Grenville Orogen were a continental arc would be comparable to that observed in continental arcs today. Our lead data for the SGA show no clear evidence for the involvement of either Archean crust or Archean sediments. No difference is observed in Fig. 2a between meta-igneous and metasedimentary rocks. As country rocks into which the granitoids were intruded might be expected to preserve a record of possible previously existing crust, the absence of any lead isotope evidence for older crust in the metasediments supports arguments for wholly juvenile crust in the Southern Grenville Orogen at $c a .1 .5 \mathrm{Ga}$. In contrast, MARCANTONIO et al. (1990) and DALY and MCLELLAND (1991) reported $c a .1 .9$ Ga old $\mathrm{Nd}$ model ages on paragneisses from the Frontenac and Adirondacks terranes. Given higher concentrations of lead than neodymium in the crust (RUDNICK and GOLDSTEIN, 1990) with respect to the mantle and mantle derived basalts, lead isotopes should be a more sensitive indicator than neodymium of previously existing upper crust (e.g., WOODEN et al.,

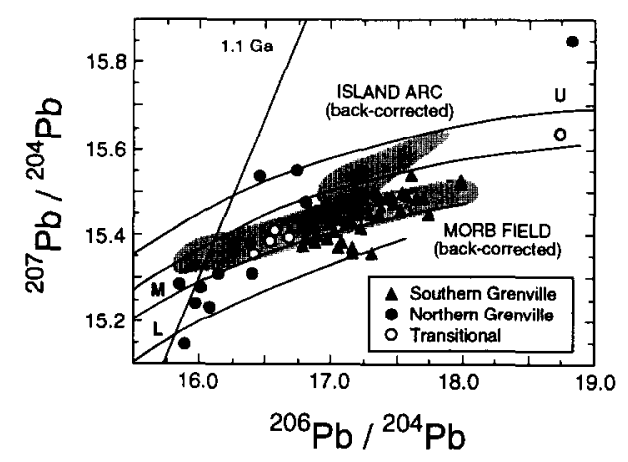

FiG. 4. All feldspar data shown in relationship with the "paleoMORB" field and field for oceanic sediments calculated from ZINDLER and HART (1986) and back-corrected to $1.1 \mathrm{Ga}$ assuming $\mu=8$.
1988). Intracrustal fractionation of $\mathrm{Sm} / \mathrm{Nd}$ may result in "old" neodymium model ages. The $\mathrm{Sm} / \mathrm{Nd}$ ratio may be increased by either sedimentary processes (e.g., AWWILLER and MACK, 1991; OHR et al., 1994), or by segregation of LREE phases (monazite, allanite) during partial melting. Most of the paragneisses from the Metasedimentary Belt and Granulite Terrane analyzed for neodymium (MARCANTONIO ct al., 1990; DALY and MCLELLAND, 1991) have greater ${ }^{147} \mathrm{Sm} /{ }^{144} \mathrm{Nd}(0.13-0.15)$ than typical crustal values $(0.105$; TAYLOR and MCLENNAN, 1985) and therefore, may have model ages that are slightly too old.

The data from the SGA (Fig. 2b) lie adjacent to the ZART. MAN and DOE (1981) curves for the evolution of upper crust and mantle indicating time integrated ${ }^{232} \mathrm{Th} /{ }^{238} \mathrm{U}(\kappa)$ similar to both the typical upper crustal and mantle values of 3.4 (ZARTMAN and DOE, 1981; TAYLOR and MCLENNAN, 1985). Due to the similarity of $\mathrm{Th} / \mathrm{U}$ of upper crust and mantle, this ratio provides no information on the presence of older upper crustal components. However, there is no displacement of the data toward the high ${ }^{232} \mathrm{Th} /{ }^{238} \mathrm{U}(\kappa)$ field for lower crust. Such a displacement may be expected if high grade metamorphism led to an increase in $\kappa$ and significantly prcceded the time of feldspar closure.

Further understanding of the evolution of the Metasedimentary Belt and Granulite Terrane is gained by comparing the data on ${ }^{208} \mathrm{~Pb} /{ }^{204} \mathrm{~Pb}$ vs. ${ }^{206} \mathrm{~Pb} /{ }^{204} \mathrm{~Pb}$ for feldspars with that for galenas (Fig. 3b). The galenas lie on the crustal and mantle growth curves. However, the feldspars, presumably becoming closed to isotopic exchange with the whole rocks 200-300 Ma later, are displaced to the right. This displacement indicates that these terranes evolved with a low $\kappa$ (ca. 1.9 ) between the time of crust formation (and early mineralization) and heating and burial during granulite facies metamorphism at ca. 1.1 Ga. Low $\kappa$ values are observed in present-day island arc volcanic and first-cycle volcanogenic sedimentary rocks, where they have been attributed to incorporation of altered MORB into the original mantle source (TAYLOR and MCLENNAN, 1985). Thus, the lead isotope data for the SGA are consistent with models that propose amalgamation of a series of juvenile arc terranes during Grenville metamorphism at 1.1 Ga (e.g., CORRIVEAU, 1990).

\section{Northern Grenville Array (NGA)}

Data from metasediments and meta-igneous rocks from the northern portion of the Gnciss Belt form an array in Fig. $2 a$ and $b$ (NGA) that is quite distinct from the SGA. As was the case in the SGA, there is no apparent difference in $\mathrm{Pb}$ isotope compositions of feldspars between orthogneisses and paragneisses within the NGA. The four samples that lie between the two arrays in Fig. 2a (91-14, GRU 83C 10, MAT $83 \mathrm{C} \mathrm{4,} \mathrm{SH88-7b;} \mathrm{shown} \mathrm{as} \mathrm{open} \mathrm{circles)} \mathrm{have} \mathrm{been} \mathrm{tenta-}$ tively assigned to the Northern Grenville array on the basis of their single stage integrated $\kappa$ (see below, Fig. 2b). Several lines of reasoning support the conclusion that the NGA results from reworking of Archean crust:

\section{Comparison with Superior Province lead data}

The lead isotope data of GARIÉPY and ALLÈGRE (1985) and GARIÉPY et al. (1990) for galenas and feldspars from 
felsic Archean rocks from the Superior Province and from the Grenville Front Tectonic Zone in Québec $(200 \mathrm{~km}$ to the east) are shown in Fig. 2. The most radiogenic feldspars of GARIÉPY et al. (1990) have ${ }^{207} \mathrm{~Pb} /{ }^{204} \mathrm{~Pb}$ and ${ }^{206} \mathrm{~Pb} /{ }^{204} \mathrm{~Pb}$ that abut those of the NGA. The feldspar data of GARIÉPY and ALLÈGRE (1985) and GARIÉPY et al. (1990) exhibits a range in ${ }^{207} \mathrm{~Pb} /{ }^{204} \mathrm{~Pb}$ (ca. 0.2 ) for the same ${ }^{206} \mathrm{~Pb} /{ }^{204} \mathrm{~Pb}$. This range is consistent with the Superior Province having a significant crustal history prior to the time of closure of these feldspars at ca. $2.5 \mathrm{Ga}$. The NGA data lie along an extension of the array of Archean feldspars. The slope of this array (ca. 0.22 ) is consistent with a (diffuse) secondary isochron with low $\mu$ values ( 1 to 8 ) resulting from closed system evolution from 2.5 to $1.1 \mathrm{Ga}$. However, this interpretation is not unique. The slope and range of this array is also consistent with mixing between Archean upper crust (high ${ }^{207} \mathrm{~Pb} /{ }^{204} \mathrm{~Pb}$ ) and lead with an isotopic composition similar to Superior Province feldspars. Either model requires Archean lead.

Charnockites from the Grenville Front Tectonic Zone in Québec (GARIEPY et al.. 1990) yield Archean mineral isochrons, and present-day whole rock lead isotope compositions record very low whole-rock $\mu$ values $(2.1-3.5)$, but high $\kappa$ values ( 7.6 to 9.4 ; Fig. $2 \mathrm{a}$ ), a common feature of high grade metamorphic rocks. These charnockites provide evidence for the existence of Archean crust at the margin of the Superior Province that developed a lower crustal lead isotope signature at 2.5-2.6 Ga. If these rocks are representative for the Archean crust in northern Ontario, they provide a mixing endmember that would result in the range of data shown in Fig. $2 b$, when mixed with juvenile crust at ca. $1.5 \mathrm{Ga}$.

\section{Relationship of the data to the relevant geochrons}

In contrast to the SGA, five samples of the NGA lie significantly to the left of the 1.1 Ga gcochron, requiring a preGrenville history including a low $\mu$ stage. Four of these data lie to the left of the $1.5 \mathrm{Ga}$ geochron and one to the left of the $1.8 \mathrm{Ga}$ geochron. For present-day lead isotopic compositions, the only rocks that lie to the left of the geochron are those from some high grade gneiss terranes from the deep crust and mafic xenoliths from such regions (RUDNICK and GOLDSTEN, 1990). These samples must have experienced a reduction in $\mu$ significantly prior to the Grenville metamorphism, most likely as a result of previous high grade metamorphism at $\gg 1.5 \mathrm{Ga}$.

Variation in ${ }^{207} \mathrm{~Pb} /{ }^{204} \mathrm{~Pb}$

The NGA data spread over a large range in both ${ }^{207} \mathrm{~Pb} /$ ${ }^{204} \mathrm{~Pb}$ and ${ }^{206} \mathrm{~Pb} /{ }^{204} \mathrm{~Pb}$ (Fig. 2a). The range in ${ }^{207} \mathrm{~Pb} /{ }^{204} \mathrm{~Pb}$ for a given ${ }^{206} \mathrm{~Pb} /{ }^{204} \mathrm{~Pb}$ (the width of the array in Fig. 2a) is much larger than for either present-day mantle derived basalts. or the SGA. Such variations can only arise through a history in which the endmember components had distinctly different $\mu$ values much earlier in Earth history. On the basis of present-day measurements of mantle-derived basalts, large $\mu$ variations apparently do not occur within the mantle but are typical for the crust.
${ }^{211 \times} \mathrm{Pb} /{ }^{204} \mathrm{~Pb}$ vs. ${ }^{206} \mathrm{~Pb} /{ }^{204} \mathrm{Ph}$ systematics

The NGA data also display a much greater range in ${ }^{208} \mathrm{~Pb} /$ ${ }^{204} \mathrm{~Pb}$ vs. ${ }^{206} \mathrm{~Pb} /{ }^{204} \mathrm{~Pb}$ than the SGA samples (Fig. 2). Calculated single-stage $\kappa$ varies, with some samples (BUR $83 \mathrm{C}$ 69. MAT 83C 21 ) lying on the ZARTMAN and DOE (1981) evolution line for the lower crust, with a single stage time integrated $\kappa$ of 5.7. In contrast to the SGA, only one sample ( $A L G$ 83C 20) lies to the right of the upper crust evolution line of ZARTMAN and DOE ( 1981 ). When present-day global lead data are viewed, the only environment in which $k$ is higher than 3.5, and variable, is material with a history in the lower crust (e.g., DOE and ZARTMAN, 1979; RUDNICK et al. 1985) and igneous rocks derived from it, all or in part. As such variations are seen in the lead isotopic composition at $1.1 \mathrm{Ga}$, fractionation in $\kappa$ occurred considerably prior to the Grenvillian high grade metamorphism. The four samples that lie between arrays in Fig. 2a all lie above the mantle evolution line in Fig. 2b, distinguishing them from the SGA.

All these lincs of reasoning support the interpretation that the NGA lead array records reworked Archean crust in the northernmost Grenville Orogen. This interpretation is consistent with U-Pb data (KROGH and WARDIE, 1984: GARIfPY et al., 1990) and neodymium model ages (DICKIN et al., 1990)
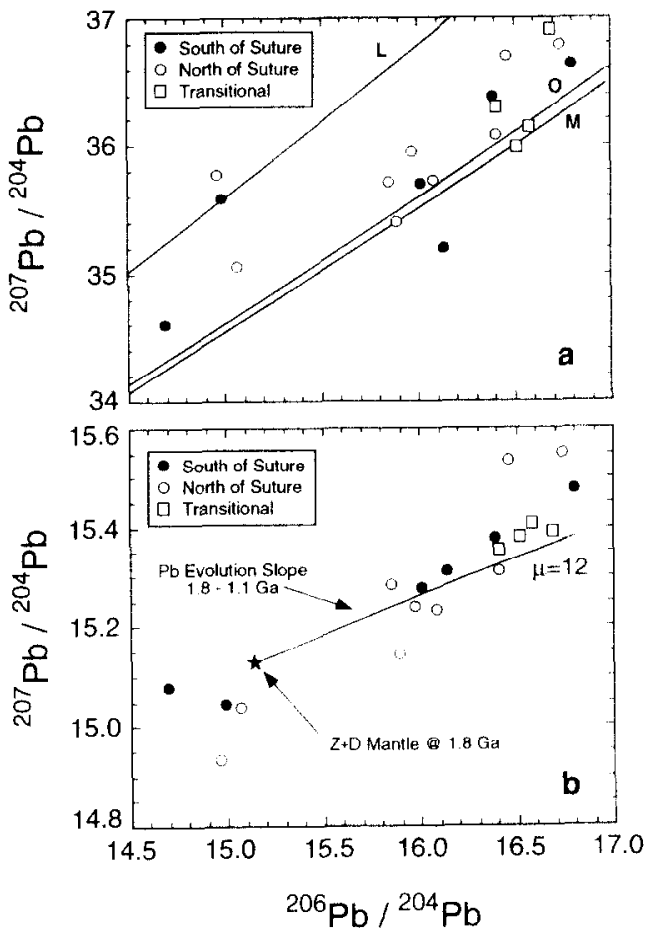

FIG. 5. A plot of lead data from the NGA and from the vicinity of the "suture" mapped by DICKIN and MCNUTT $(1989,1990)$ and DickIN et al. ( 1990 ) shows no clear distinction between lead isotopes from north or south of the proposed suture. The $\mathrm{Nd}$-model ages for rucks from this area are about $1.8 \mathrm{Ga}$ (DICKIN and MCNUTT, 1989 , 1990: DICKIN et al., 1990). If the spread in Pb-isotopes was caused by $\mathrm{Pb}$-growth this evolution must have started significantly prior to $1.8 \mathrm{Ga}$ as indicaled by the line depicting growth from $1.8 \mathrm{Ga}$ (the values of the Nd-model ages) to $1.1 \mathrm{Ga}$ (the last thermal equilibration) with $\mu=12$ and starting at the model mantle of ZARTMAN and DOE (1981). 
from the vicinity of the Grenville Front Tectonic Zone. However, the NGA data field extends farther south than the "suture" identified by DiCKIN and MCNUTT $(1989,1990)$ based on a transition in neodymium model ages from $>2.5$ Ga to ca. $1.8 \mathrm{Ga}$. Fig. 5 shows the NGA data from north and south of the proposed "suture". Also plotted is a secondary isochron representing growth from 1.8 to $1.1 \mathrm{Ga}$ starting from a calculated initial mantlc composition as proposed by ZARTMAN and DOE (1981). There is no clear distinction in lead isotopic composition between feldspars from the two sides of the "suture". In a ${ }^{207} \mathrm{~Pb} /{ }^{204} \mathrm{~Pb}$ vs. ${ }^{206} \mathrm{~Pb} /{ }^{204} \mathrm{~Pb}$ diagram the data points from north of the proposed suture define a slightly steeper array than the data from south of the proposed suture (Fig. 5). In any case, these slopes are significantly steepcr than $\mathrm{Pb}$-growth from 1.8 to $1.1 \mathrm{Ga}$ required by the model of DICKIN and MCNUTT $(1989,1990)$. No systematic difference is apparent in a ${ }^{208} \mathrm{~Pb} /{ }^{204} \mathrm{~Pb}$ vs. ${ }^{206} \mathrm{~Pb} /{ }^{204} \mathrm{~Pb}$ diagram (Fig. 5) across the inferred Archean-Penokean suture of DICKIN and MCNUTT (1989, 1990). The least radiogenic feldspars, which have isotopic compositions similar to the Archean feldspars of GARIÉPY et al. (1990; Fig. 2), occur south of the suture. The slope of the array formed by the NGA data south of the suture is consistent with a secondary isochron starting at $1.8 \mathrm{Ga}$, and second stage $\mu$ values of ca. 12 to 15 . However, the least radiogenic points in ${ }^{207} \mathrm{~Pb} /{ }^{204} \mathrm{~Pb}$ lie below the model mantle compositions. When allowing for a variation of ca. 0.1 in ${ }^{207} \mathrm{~Pb} /{ }^{204} \mathrm{~Pb}$ in mantle derived basalts, the MORB field would include these points. However, preservation of this lead isotopic composition would require derivation from the mantle, followed by immediate reduction in $\mu$ (to $\mu=0$ ), with no subsequent increase in ${ }^{207} \mathrm{~Pb} /{ }^{204} \mathrm{~Pb}$ or ${ }^{206} \mathrm{~Pb} /{ }^{204} \mathrm{~Pb}$ over $700 \mathrm{Ma}$ until metamorphism at $1.1 \mathrm{Ga}$. Further, these same two points have vastly different ${ }^{208} \mathrm{~Pb} /$ ${ }^{204} \mathrm{~Pb}$ for a given ${ }^{206} \mathrm{~Pb} /{ }^{204} \mathrm{~Pb}$. This requires evolution in an environment with variable $\mathrm{Th} / \mathrm{U}$ and is not compatible with derivation from the mantle at $1.8 \mathrm{Ga}$, and with immediate reduction in $\mu$. Therefore, these points require the presence of an older component; based on the geologic environment and the lead data presented here, this component is most likely Archean.

\section{Shear Zone Data}

Data from three different shear zones that were active during the Grenville orogeny have distinct isotopic characteristics (Table 1). Data from the Grenville Front Tectonic Zone (three of four samples) lie above the ${ }^{207} \mathrm{~Pb} /{ }^{204} \mathrm{~Pb}$ vs. ${ }^{206} \mathrm{~Pb}$ / ${ }^{204} \mathrm{~Pb}$ arrays formed by the rest of the Grenville data in Fig. 2a; two of these data lie above the ZARTMAN and DOE (1981) line for the evolution of upper crust lead. This position requires both an old lead component and a high $\mu$. Data from the Metasedimentary Belt Boundary Zone lie below the field for the Metasedimentary Belt, suggesting mixing with an older lower crustal lead component. There is no other evidence for a lead component older than $1.5 \mathrm{Ga}$ in this region of the Grenville. Finally, sample 90-60 (not shown in diagrams) is from within the Carthage-Colton shear zone which separates the Adirondack Lowlands from the Adirondack Highlands. This sample has a high ${ }^{206} \mathrm{~Pb} /{ }^{204} \mathrm{~Pb}$ but not ${ }^{207} \mathrm{~Pb} /{ }^{204} \mathrm{~Pb}$, which may suggest late (Phanerozoic?) reequilibration of the feldspar with the host rock due to post orogenic movement along the fault. Although the exact nature of the lead systematics of shear zone feldspars is unclear from this limited set of data, element transfer and fluid migration along shear zones can be expected, and these processes may be monitored by (re)crystallizing feldspars.

\section{DISCUSSION}

\section{Geographic Extent of Archean Lead Signature}

Figure 6 shows the geographic distribution of the NGA feldspars and the neodymium model age boundaries of DICKIN and MCNUTT (1990). The Archean lead component extends as far as $180 \mathrm{~km}$ south of the Grenville Front, and includes the Britt, Kiosk, and Algonquin Domains. Comparison with the neodymium model ages shows that the lead boundary corresponds reasonably well, with the boundary between ca. 1.5 Ga model ages and older ages. For example, the $\mathrm{Pb}$-boundary between samples $91-14$ and $91-15$ in the southern Britt Domain coincides with a decrease in neodymium model ages from 1.98 to $1.46 \mathrm{Ga}$ in the same area. The $\mathrm{Pb}$-boundary defined in the south by sample LNT-83c- 2 corresponds to the region where neodymium model ages decrease from 1.90 to $1.66 \mathrm{Ga}$. Sample GRU 83C 4 corresponds well with lower neodymium model ages in the Parry Sound Domain (DICKIN and MCNUTT, 1990). The boundary between ca. $1.8 \mathrm{Ga}$ neodymium model ages and Archean lead signature and ca. $1.5 \mathrm{Ga}$ neodymium modcl ages and juvenile lead signature does not strictly follow Grenville age structures that are currently known from mapping (DAvidSON, 1984). For example, the boundary appears to transect the Britt Domain, and possibly the southern Kiosk Domain. This transection indicates that the neodymium and lead isotopes record an old pre-Grenville boundary in the ultimate source regions that produced the felsic rocks which were sampled. However, more detailed sampling is required to correlate Grenville structures with the isotopic boundary.

The lack of any clear distinction in lead isotopic composition between feldspars from the two sides of the "suture" is striking, because based on the differences in neodymium model ages, this should be the most fundamental transition in the Grenville Orogen of Ontario (DICKIN and MC NUTT, 1990). In addition, seismic imaging of the northern Grenville Orogen and Grenville Front shows no evidence for any major suture south of the Grenville Front Tectonic Zone (GREEN et al., 1988). There is a discrepancy concerning the crustal age of the segment with the Penokean model ages (around $1.8 \mathrm{Ga}$ ) and the Archean lead signature. A possible explanation for the different isotopic signatures is that the neodymium model ages represent mixing of Archean components with ca. $1.5 \mathrm{Ga}$ juvenile additions.

A significant problem in resolving between the two alternatives of crust formation during the Penokean orogeny and a mixture of old (Archean) with young crustal matcrial (ca. $1.5 \mathrm{Ga}$ ) during the Grenvillian orogeny is the scarcity of $\mathrm{U}$ $\mathrm{Pb}$ zircon data and the virtual absence of old $(>1.5 \mathrm{Ga})$ zircon ages from the northern Gneiss Belt. The lack of old zircon ages may result in part from a sampling bias toward plutons and away from gneisses. In the Gneiss Belt, known igneous 


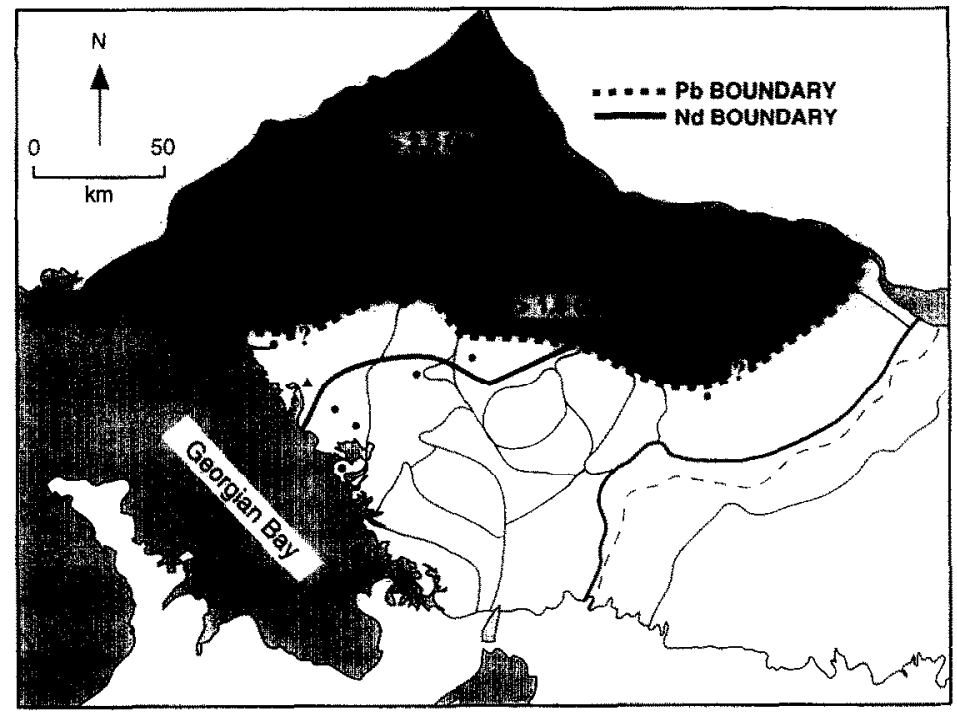

FiG . 6. Map of the Gneiss Belt, showing location of Nd boundaries of DICKIN and MCNUTT (1990). The northern boundary is the Archean-Penokean and the southern boundary the Penokean-Grenvillian suture as suggested by DICKIN and MCNUTT (1990). A possible lead isotopic boundary is also shown as a dashed line. (triangles = NGA; circles $=$ SGA).

crystallization ages are generally younger than $1.5 \mathrm{Ga}$ (EASTON. 1986). The only published evidence for earlier magmatism that would support a Penokean island arc are: (1) a $1.74 \mathrm{Ga}$ age for the Killarney Complex (VAN BREEMEN and DAVIDSON, 1988); (2) a poorly defined ca. $1.68 \mathrm{Ga}$ upper intercept age for a leucogranite in the Key Harbour region of the Britt Domain (CORRIGAN, 1990); (3) a Rb-Sr wholerock age of $1810 \pm 11 \mathrm{Ma}$ for the French River Paragneiss (KROGH and DAVIS, 1972), and (4) a poorly defined zircon upper intercept greater than ca. 1.68 Ga (KROGH and DAvIS, 1972). Of these, only the Key Harbour Granite lies in the area mapped as Penokean by DICKIN and MCNUTT (1990). The nearest recognized Penokean age volcanic rocks occur several hundred kilometers to the west in Michigan and Wisconsin (e.g., BickFord et al., 1986; BAROVICH et al., 1989). In Ontario, well-defined Archean zircon ages have only been recorded from the Grenville Front Tectonic Zone (see EASTON, 1986).

The $\mathrm{U}-\mathrm{Pb}$ zircon evidence for widespread magmatism at 1.5 Ga provides the most likely explanation for the observed neodymium and feldspar lead data via mixing of juvenile (1.5 Ga) mantle-derived material with Archean crust. These mixtures may yield intermediate neodymium model ages with no geologic age significance without noticeably affecting the lead array. The geometry of the lead evolution curves (Fig. $2 a$ ) in the middle Proterozoic result in the juvenile mantle derived crust having a lead isotopic composition not very different from a mixture of evolved upper and (low $\mu$ ) lower crust. The relationship between the lead isotope composition of Archean lower crustal rocks and the NGA feldspars suggests the possibility of mixing, but it is not possible to document the extent of mixing because such a process would depend on the $\kappa$ of the Archean component, which is not known. Since continental crust has higher $\mathrm{Pb} / \mathrm{Nd}$ than basalt ( 7 and
2, respectively; RUDNICK and GOLDSTEIN, 1990), the neodymium model age may be changed without affecting the lead signature.

Model concentration data for basalts and for crustal rocks (DICKIN, 1981; TAYLOR and MCLENNAN, 1985) may be used to model mixing hetween Archean crust and mid-Proterozoic mantle derived basalts. Figure 7 shows that mixing of $90 \%$ juvenile material with $10 \%$ model Archean upper crust

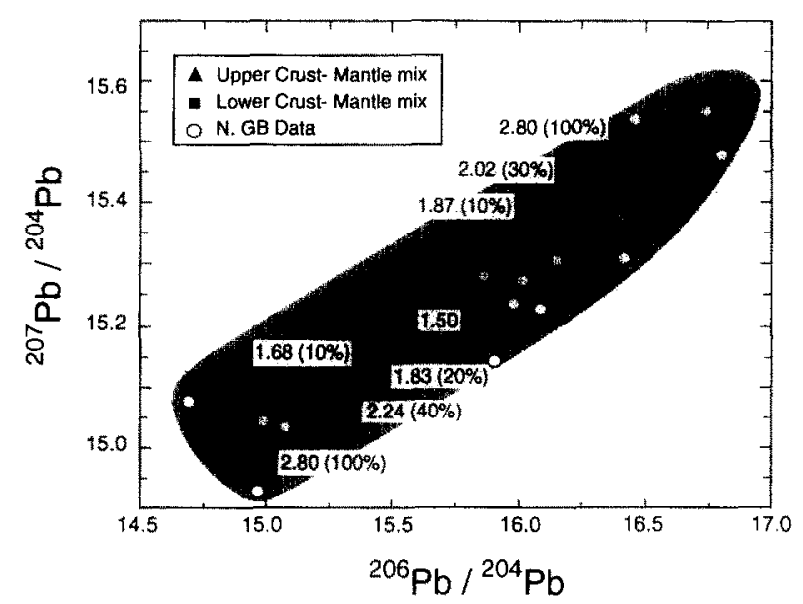

FIG. 7. Effect of mixing preexisting Archean crust with juvenile evolved mantle-derived crust at 1.5 Ga on lead isotopic compositions and on neodymium model ages (numbers). Lead and neodymium concentrations of endmembers are as follows: mantle: $\mathrm{Nd}=15 \mathrm{ppm}$ (TAYLOR and MCLENNAN, 1985), Pb = 3 ppm; Lower Crust: Nd $=12$ ppm, $\mathrm{Pb}=4 \mathrm{ppm}$; Upper Crust: $\mathrm{Nd}=25 \mathrm{ppm}, \mathrm{Pb}=20 \mathrm{ppm}$ (TAYLOR and MCLENNAN, 1985). Lead isotopic compositions are the model compositions of ZARTMAN and DOE (1981) at 1.5 Ga: Numbers in parentheses are the amount of Archean crust in $\%$ mixed with juvenile material. 
(ZARTMAN and DOE, 1981 ) reduces the neodymium model age to $1.87 \mathrm{Ga}$ without completely erasing the Archean lead isotope signature. Figure 7 also displays the expected results for mixing of Archean lower crust and mantle derived basalt at $1.5 \mathrm{Ga}$. Due to the apparent lower abundance of lead in the lower crust (TAYLOR and MCLENNAN, 1985), addition of mantle-derived basalt may have a greater impact on the lead isotopic composition. In this case, $10 \%$ old crust displaces the lead isotopes only a small amount from the mantle composition.

The lead data from the NGA are consistent with mixing of older crust with a juvenile mantle-derived component at either 1.8 or $1.5 \mathrm{Ga}$. However, because the concentration of neodymium in the upper crust and mantle-derived basalt is similar, this model is incompatible with neodymium model ages of $1.8 \mathrm{Ga}$ since mixing of Archean and $1.8 \mathrm{Ga}$ old material would have to yield neodymium model ages that are significantly older than $1.8 \mathrm{Ga}$. We prefer a simpler interpretation that is consistent with U-Pb evidence for widespread magmatism throughout the (now assembled) Grenville Orogen at 1.5-1.3 Ga (DICKIN and HigGiNS, 1992), and with the clustering of neodymium model ages at $1.4-1.5 \mathrm{Ga}$ in the outboard Grenville Orogen. At the margin of the Archean craton, mixing of juvenile mantle-derived material with Archean crust generated crust that preserves an Archean lead signature and yields neodymium model ages between the Archean and middle Proterozoic time of new crust generation. In this model, the rocks that yield model ages around $1.8 \mathrm{Ga}$ are considered to represent a mixing zone and not a juvenile Penokean terrane, as suggested by DICKIN and MCNUTT (1989, 1990) and DICKIN et al. (1990). WOODEN et al. (1988) used a similar explanation to account for coexisting Archean lead signatures and mid-Proterozoic neodymium model ages for Precambrian rocks of southeastern California. In their model, mid-Proterozoic island arcs were contaminated by detritus with radiogenic lead with high ${ }^{206} \mathrm{~Pb} /{ }^{204} \mathrm{~Pb}$ from $\mathrm{Ar}$ chean crust. This model may not be operative in the case of the Gneiss Belt, because the lead signature is typical of Archean lower rather than upper crust. Therefore, a model can be envisioned where mantle derived juvenile melts material are added to the crust and assimilate lower crustal material before finally crystallizing in the crust. Since both meta-sediments and meta-igneous rocks are indistinguishable based on their isotopic character, it is also possible that some of the mixing occurred in the sedimentary cycle.

The contrast between the model presented here and the interpretation of DICKIN and MCNUTT $(1989,1990)$ and DICKIN et al. (1990) illustrates the importance of a multidisciplinary approach to terrane delineation which combines lithologic and field constraints with lead isotopes, $\mathrm{U}-\mathrm{Pb}$ zircon data and neodymium model ages in order to develop reasonable and robust interpretations of terrane boundaries and crustal provenance.

\section{Lead Behavior in the Deep Crust During Orogenesis}

The presence of gneisses with both high and low $\mu$ histories in the Gneiss Belt at deep crustal levels $(35-45 \mathrm{~km}$ ) resembles the frozen-in orogenic mixing envisioned in the plumbotectonics models (ZARTMAN and DOE, 1981). This incomplete mixing is different from that envisioned by RUDNICK and GOLDSTEIN (1990) for the lowermost continental crust. Based on lower crustal xenoliths they proposed that the lower crust develops an "upper crustal signature" during orogenesis. In the Gneiss Belt, which in terms of its P-T evolution had a history similar to many xenoliths presumably exhumed from the base of the crust, an unradiogenic lead signature is preserved. Thus, while some mixing of lower and upper crustal lead undoubtedly occurs during orogenesis, the lower crust can apparently remain largely isolated from the other major earth reservoirs. Large portions of the lower and middle crust may be able to maintain a low $\mu$ character and unradiogenic lead signature despite high-grade metamorphism.

\section{Metamorphic Geotherms and P-T Paths}

In the Grenville Orogen, distinctly different metamorphic geotherms have been reported for the Gneiss Belt, the Metasedimentary Belt, and the Adirondack Highlands of the Granulite Terrane (ANOVITZ and ESSENE, 1990; BoHLEN et al., 1985). Peak temperatures of $750-800^{\circ} \mathrm{C}$ occur at pressures of 7-8 kb in the Adirondack Highlands (BOHLEN et al., 1985), whereas similar peak temperatures occur at pressures of $10-12 \mathrm{~kb}$ in the Gneiss Belt. This difference results in estimates of about $35^{\circ} \mathrm{C} / \mathrm{km}$ and $20^{\circ} \mathrm{C} / \mathrm{km}$, respectively, for the metamorphic geotherm.

ENGLAND and THOMPSON ( 1984 ) and other workers have modeled the P-T paths followed during an orogenic cycle involving the rapid double thickening of the continental crust. Such a model has been generally accepted for the Gneiss Belt (e.g., MEZGER et al., 1991b). However, this thrusting model is not able to explain the steep geothermal gradients characteristic for the metamorphism in the Metasedimentary Belt and the Granulite Terrane. The steep geothermal gradients are usually postulated to result from underplating of basaltic magmas at the base of the crust (e.g., BOHLEN and MEZGER, 1989 ) or are caused by a delay of 20-50 Ma in uplift (SPEAR and PEACOCK, 1989), which in effect, insulates a buried portion of upper crust with typically high heat production.

The feldspar lead data indicate that a large portion of the currently exposed Gneiss Belt experienced a low $\mu$ history for several hundred Ma prior to the final phase of Grenville metamorphism at $1.1 \mathrm{Ga}$. The combination of low $\mu$ and high $\kappa$ suggests that this low $\mu$ history resulted from a depletion in uranium, a characteristic of crust that has expcricnced granulite facies metamorphism (e.g., RUDNICK et al., 1985). In places, there is evidence for pre-Grenville metamorphism in the Gneiss Belt and Grenville Front Tectonic Zone (KROGH and DAVIS, 1972; VAN BREEMEN and DAVIDSON, 1988; GARIÉPY et al., 1990; TUCCILlO et al., 1992). Although many factors, most likely the movement of melts through the crust, may impact the observed metamorphic gradients, the difference in the thermal regime between the juvenile part of the Grenville Orogen and the Gneiss Belt can easily be explained by reduced heat production in the older lower crust of the Gneiss Belt. Whereas this explanation is relevant 
for the Ottawa-Boncherre Graben, Tomiko-Burwash, Algonquin, Kiosk, and part of the Britt domains (Fig. 1), it does not explain the low geothermal gradient observed in the Muskoka-Sequin domain (included in the SGA in Fig. 1) without invoking the presence of previously depleted crust buried at depth. However, it is interesting to note that nappe tectonics with its associated low geothermal gradient occurred in the depleted parts of the Grenville Orogen, whereas thrusting seems to be of minor importance in the juvenile undepleted parts of the orogen.

\section{SUMMARY}

Lead isotopic compositions of leached feldspars and muscovite provide important constraints on the pre-metamorphic history of the Grenville Orogen of Ontario and New York. The isotopic signatures preserved in K-feldspars from the northern Gneiss Belt require both the presence of an Archean crustal component, and a reduction in whole-rock $\mu$ values several hundred Ma prior to high grade metamorphism at ca. $1.1 \mathrm{Ga}$. Lead isotopic compositions of leached feldspars are sensitive indicators of crustal history, and provide a complement to neodymium model ages and $\mathrm{U}-\mathrm{Pb}$ zircon ages in the delineation of terrane boundaries in ancient orogens. Through a combination of these data, it is possible to delinate ancient terrane boundaries, despite subsequent extensive tectonism and high grade metamorphism. The ages of different crustal segments provide essential information for a tectonic reconstruction of the history of the orogen and the importance of plate movement during the Grenville orogeny. Isotopes are the only means by which it is possible to reconstruct the early history of the deeply eroded root of the Grenville Orogen. In this specific example, the combination of lead and neodymium isotopes was essential to distinguish between juvenile and mixed crust. Due to the inverse relationship of $\mathrm{Pb} / \mathrm{Nu}$ in crust and mantle material, use of only lead would have lead to an overestimate of Archean crustal material and use of neodymium only to the suggestion of an important crust forming event that was essentially only a result of mixing ancient with juvenile material. The combined isotope data also provides strong evidence that large parts of the Grenville Orogen consist of juvenile material and that mixing of Archean with juvenile crustal material is restricted to a $50-70 \mathrm{~km}$ wide zone.

Acknowledgments-The authors would like to acknowledge helpful discussions with J. L. Wooden, E. J. Krogstad, S. J. G. Galer. and S. L. Goldstein. Portions of this work were funded by NSF grants $90-$ 04302 and 91-17772. CPD thanks the Max-Planck-Society for support during his stay at Mainc. R. Keller provided quality technical assistance with the mass spectrometry. D. Austin helped with the drafting of some of the figures. The critical comments of E. J. Essene, A. N. Halliday, and B. A. van der Pluijm are appreciated and greatly improved the quality of the manuscript. Extremely helpful and constructive reviews were provided by $B$. R. Doe. J. Kramers, and F. Oberli.

\section{REFERENCES}

ANOVIIZ L. M. and ESSENE 1 J. (1990) Thermobarometry and pressure-temperature paths in the Grenville Orogen of Ontario. $J$ Pelrol. 31, 197-241.

ARNDT N. T. and GoLDSTEIN S. 1.. (1987) Use and abuse of crustformation ages. Gowlogy 15, 893-895

AWWILER D. N. and MACK L. E. ( 1991 ) Diagenetic modifications of $\mathrm{Sm}-\mathrm{Nd}$ model ages in Tertiary sandstones and shales. Texas Gulf Coast. Golog! 19,31!-314.

AYUSO R. A. and BEYIER M. I.. (1991) Regional differences in $\mathrm{Pb}$ isotopic compositions of feldspars in plutonic rocks of the northern Appalachian Mountains. U.S.A. and Canada: A geochemical method of terrane correlation. Tertonics 10, 191-212.

Barovich K. K.. Patchett P. J.. Pfterman Z. E... and Sims P. K. (1989) Hf isotopes and the origin of 1.9-1.7 Ga Penokean continental crust of the Lake Superior region. G.S.1. Bull. 101, 333338 .

BICKFORD M. E., VAN SCHMUS W. R., and ZEITL I. (1986) Proterozoic history of the midcontinent region of North America. Geology 14, 492-496

BoHI.N S. R. and MEZGLR K. (1989) Origin of granulite terranes and the formation of the lowermost continental crust. Science 244 , $326-329$

BOHLL S. R., VALley J. W., and ESSENE E. J. (1985) Metamorphism in the Adirondacks. I. Petrology, pressure, and temperature. J. Proll 26, 971-992.

BIIDDINGiTON A. F. (1934) Adirondack igneous rocks and their metamorphism (i.S.A. M'm. 7,354 pp.

BuIRTON K. W. and ONiovs R. K. (1991) High-resolution garnel chronometry and rates of metamorphic processes. Earth Planct. Sit. I.cti 107, 649-671.

(hamberlain K. R. and Bowrive; S. A. (1990) Proterozoic geochronologic and isotopic boundary in NW Arizona. I G(ial. 98. $399-416$

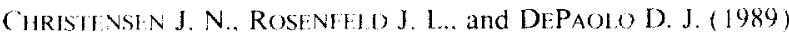
Rates of tectonometamorphic processes from rubidium and strontium isotopes in garnet. Siche' 244, 1465-1468.

CORRIVEall I.. (1990) Proterozoic subduction and terrane amalgamation in the southwestern Grenville Orogen, Canada, evidence from ultrapotassic to shoshonitic plutonism. Go/og' 15, 614-617.

CORRIGAN D. (1990) Geology and Geochronology of the Key Harhour area. Britt Domain, Grenville Orogen of Ontario. M.Sc. Thesis. Dalhousie Univ. Halifax, Nova Scotia.

ClloTta R. C.. PRATT T., and Ol.IVER J. (1990) A tale of two sutures: COCORP's deep seismic surveys of the Grenville Orogen in the castern U.S. midcontinent. Geology 18, 646.649.

CulshaW N. G.. Davidoson A., and NADEAU L. (1983) Structural subdivisions of the Grenville Orogen in the Parry Sound-Algonquin region, Ontario. In Curren Reseath. Part B: Gersl. Surv. Canada Pap. 83-IB. pp. 243-25?.

DALY J. S. and MC LElLAND J. M. (1991) Juvenile Middle Proterozoic crust in the Adirondack Highlands, Grenville Orogen, northeastern North America. Goology 19, 119-122.

DAvidsos A. (1984) Identification of ductile shear zones in the southwestern Girenville Orogen of the Canadian Shield. In Proiambrian Tactonics Illustrated, (ed. A. KRONER and R. GRELLING) pp. 26.3-279. E. Schweizerbart sche Verlagbuchhandlung.

DAvIDSON A. (1986) New interpretations in the southwestern Grenville Oregon. In The Grenville Orogen; Geol. Assoc. Canada Spec: lap. 31, pp. 61-74

Davidson A., CulshaW N. G., and NADEAU L. (1982) A tectonometamorphic framework for part of the Grenville Orogen, Parry Sound Region. Ontario. In Carremt Research, Part 1, Geol Surs. ('anada Pap. 82-1.1, pp. 175-190.

DAvidsov 1. P. ( 1986 ) Isotopic and trace element constraints on the petrogenesis of subduction-related lavas from Martinique. lesser Antilles. J. Geophts. Res. 91, 5943-5962.

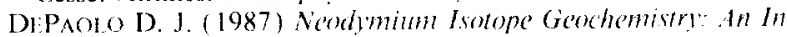
frodution Springer-Verlag.

TRKF K. C. A. (1973) Tibetan, Variscan and 
Precambrian basement reactivation, products of continental collision. J. Geol. 81, 683-692.

DickIN A. P. (1981) Isotope geochemistry of Tertiary igneous rocks from the isle of Skye, NW Scotland. J. Petrol. 22, 155-189.

DICKIN A. P. and HigGiNs M. D. (1992) Sm/Nd evidence for a major $1.5 \mathrm{Ga}$ crust-forming event in the Grenville Orogen. Geology 20, $137-140$

DickIN A. P. and MCNUTT R. H. (1989) Nd model age mapping of the southeast margin of the Archean foreland in the Grenville Orogen of Ontario. Geology 17, 299-302.

DickiN A. P. and MCNUTT R. H. (1990) Nd model-age mapping of Grenville lithotectonic domains, mid-Proterozoic crustal evolution in Ontario. In Mid-Proterozoic Laurentia-Baltica; Geol. Assoc. Canada Spec. Pap. 38, pp. 79-94.

DiCkin A. P.. MCNUTT R. H., and ClifFord P. M. (1990) A neodymium isotope study of plutons near the Grenville Front in Ontario, Canada. Chem. Geol. 83, 315-324.

DOE B. R. (1962) Rclationships of lead isotopes among granites, pegamatites, and sulfide ores near Balmat, New York. J. Geophys. Res. 67, 2895-2906.

DOE B. R. (1967) The bearing of lead isotopes on the source of granitic magma. J. Petrol. 8, 51-83.

DOE B. R. and ZaRTMAN R. E. (1979) Plumbotectonics-the Phanerozoic. In Geochemistry of Hydrothermal ore deposits (ed. $\mathrm{H}$. L. BARNES), pp. 22-70. Wiley.

EASTON R. M. (1986) Geochronology of the Grenville Orogen. In The Grenville Orogen; Geol. Assoc. Canada Spec. Pap. 31, pp. 127-137.

ENGEL A. E. J. and ENGEL C. G. (1953) Grenville series in the northwest Adirondacks Mountains, New York, part I, General features of the Grenville seires. Bull. G.S.A. 64, 1014-1048.

ENGLAND P. C. and Thompson A. B. (1984) Pressure-temperaturetime paths of regional metamorphism I: heat transfer during the evolution of regions of thickened continental crust. J. Petrol. 25, 894-928.

FLETCHER I. R. and FARQUHAR R. M. (1982a) The protocontinental nature and regional variability of the Metasedimentary Belt of the Grenville Orogen. Canadian J Earth Sci 19, 239-253.

FLeTCHER I. R. and FARQUHAR R. M. (1982b) Lead isotopic compositions of Balmat ore and their genetic implications. Econ. Geol. $77,464-473$.

Gariépy C. and ALLÈGRE C. J. (1985) The lead isotope geochemistry and geochronology of late-kinematic intrusives from the Abitibi greenstone belt, and the implications for late Archaen crustal evolution. Geochim. Cosmochim. Acta. 49, 2371-2383.

Gariépy C., Verner D., and Dolg R. (1990) Dating Archean metamorphic minerals southeast of the Grenville Front, western Quebec, using Pb isotopes. Geology 18, 1078-1081.

Green A. G. Milkereit B., Davidson A., Spencer C., BehrRENDT W. F., and HINZE W. J. (1988) Crustal structure of the Grenville Front and adjacent terranes. Geology 16, 788-792.

GraUCH R. (1989) Rare earth elements in metamorphic rocks. In Geochemistry and Mineralogy of Rare Earth Elements; Rev. Mineral. 21 , pp. 147-168.

HANMER S. (1988) Ductile thrusting at mid-crustal levels, southwestern Grenville Orogen. Canadian J. Earth Sci. 25, 1049-1059.

Heaman L. M., Shieh Y. N., MCNUTt R. H., and Shaw D. M. (1982) Isotopic and trace element study of the Loon Lake Pluton. Grenville Province, Ontario. Canadian J. Earth Sct. 19, 10451054.

HEIER K. S. (1973) Geochemistry of granulite facies rocks and problems of their origin. Philos. Trans. Roy. Soc. London Ser. A 273, 429-442.

Housh T., Bowring S. A., and Villemueve M. (1989) Lead isotopic study of Early Proterozoic Wopmay Orogen, NW Canada, role of continental crust in arc magmatism. J. Geol. 97, 735-747.

KROGH T. E. and DAvis G. L. (1972) The effect of regional metamorphism on U-Pb systems in zircons and a comparison with $\mathrm{Rb}$ Sr systems in the same whole rock. Carnegie Inst. Wash. Year. 71, 564-571

KROGH T. E. and HURLEY P. M. (1968) Strontium isotope variation and whole-rock isochron studies, Grenville province of Ontario. J. Geophys. Res. 73, 7107-7125.

KROGH T. E. and WARDLE R. (1984) U-Pb isotopic ages along the Grenville Front. Geol. Assoc. Canada Prog, 9, 80.

Liew T. C., Milisenda C. C., and Hoffman A. W. (1991) Isotopic contrasts, chronology of elemental transfers and high grade metamorphism, the Sri Lanka Highland granulites, and the Lewisian (Scotland) and Nuk (SW Greenland) gneisses. Geol. Rundschau $\mathbf{8 0}, 279-288$.

LUDWIG K. R. and SILVER L. T. (1977) Lead-isotope in homogeneity in Precambrian igneous K-feldspars. Geochim. Cosmochim. Acta 41. 1457-1471.

Lumbers S. B., Heaman L. M., Vertolli V. M., and WU T. W (1991) Nature and timing of middle Proterozoic magmatism in the Metasedimentary Belt. Grenville Orogen, Ontario. In MidProterozoic Laurentia-Baltica: Geol. Assoc. Canada Spec. Pap. 38 , pp. 243-275.

Marcantonio F., McNutt R. H., Dickin A. P., and Heaman L. M. (1990) Isotopic evidence for the crustal evolution of the Frontenac Arch in the Grenville Orogen of Ontario, Canada. Chem. Geol 83, 297-314.

MCLelland J., Chiarenzelli J., Whitney P., and ISAChSEN Y. (1988) U.Pb zircon geochronology of the Adirondack Mountains and implications for their geologic evolution. Geology 16, 920924.

MEZGer K., HANSEN G. N., and BoHLen S. R. (1989) U.Pb systematics of garnet in the late Archean Pikwitonei granulite domain at Cauchon and Natawahunan Lakes, Manitoba, Canada. Contrib. Mineral. Petrol. 101, 136-148.

MEZGer K., RawnSley C. M., Bohlen S. R., and HaNSON G. N. (1991a) U-Pb garnet, sphene, monazite and rutile ages, implications for the duration of high-grade metamorphism and cooling histories, Adirondack Mts., New York. J. Geol. 99, 415-428.

Mezger K., van der Pluijm B. A., Essene E. J., and Halliday A. N. (1991b). Synorogenic collapse, a perspective from the middle crust, the Proterozoic Grenville Orogen. Science 254, 695-698.

Mezger K., VAN DER Plunm B. A., Essene E. J., and Halliday A. N. (1993) U-Pb geochronology of the Grenville Orogen of Ontario and New York; constraints on ancient crustal tectonics. Contrib. Mineral. Petrol 114, 13-26.

Milisenda C. C., Liew T. C., Hofmann A. W., and Króner A. (1988) Isotopic mapping of age provinces in Precambrian highgrade terrains: Sri Lanka. J. Geol. 96, 608-615

MOORBATH S. WELKE H., and GALE N. H. (1969) The significance of lead isotope studies in ancient high grade metamorphic basement complexes, as exemplified by the Lewisian rocks of Northwest Scotland. Earth Planet. Sci. Lett. 6, 245-256.

NELSON B. K. and DEPAOLO D. J. (1985) Rapid production of continental crust 1.7 to 1.9 b.y. ago: Nd isotopic evidence from the basement of the North American mid-continent. G.S.A. Bull. 96 , $746-754$.

OHR M., HaL.liday A. N.. PEACOR D. R., and Delano J. W. (1994) Low-temperature mobility and fractionation of rare earth elements in argillaceous sediments: Potential for dating early diagenesis and metamorphism. Geochim. Cosmochim. Acta 58, 289-312.

PATCHETT P. J. (1992) Isotopic studies of Proterozoic Crustal Growth and Evolution. In Proterozoic Crustal Evolution: Dev. Precambrian Geol. 10. pp. $481-508$.

RUDNICK R. L. and Goldstein S. L. (1990) The Pb isotopic compositions of lower crustal xenoliths and the evolution of lower crustal Pb. Earth Planet. Sci. Lett. 98, 192-207.

RUDNICK R. L., MCLENNAN S. M., and TAYLOR S. R. (1985) Largeion-lithophile elements in rocks from high-pressure granulite facies terrains. Geochim. Cosmochim. Acta 49, 1645-1655.

SPEAR F. S. and PEACOCK S. M. (1989) Metamorphic Pressure-Temperature-Time Paths; Amer. Geophys. Union. Short Course in Geology, ?

TAYLOR S. R. and MCLENNAN S. M. (1985) The Continental Crust: Its Composition and Evolution. Blackwell Scientific.

TILTON G. R. (1983) Evolution of depleted mantle. Geochim. Cosmochim. Acta 47, 1191-1197. 
Tuccillo M. E., Mezger K., Essene E. J., and van der Pluijm B. A. (1992) Thermobarometry, geochronology, and the interpretation of P-T-t data in the Britt Domain, Ontario Grenville Orogen, Canada. J. Petrol. 33, 321-329.

VAN BREEMEN O. and DAVIDSON A. ( 1988 ) Northeast extension of Proterozoic terranes of mid-continental North America. G.S.A. Bull. 100, 630-638.

VAN BREemeN O. and DAVIDSON A. (1990) U-Pb zircon and baddelyite ages from the Gneiss Belt, Ontario. In Radiogenic Age and Isotopic Studies, Rept. 3; Geol. Surv. Can. Pap. 89-2. pp. $85-92$.

VAN BREEMEN O. and HANMER S. ( 1986 ) Zircon morphology and $\mathrm{U}-\mathrm{Pb}$ geochronology in active shear zones, studies on syntectonic intrusions along the northwest boundary of the $\mathrm{CMB}$, Grenville Orogen, Ontario. In Current Research. Part B: Geol. Surv. Canada Pap. 86-lB, pp. $775-784$.

WOODEN J. L. and MUELleR P. A. ( 1987) Pb, Sr, and Nd isotopic compositions of a suite of Latc Archean igneous rocks. eastern
Beartooth Mountains, implications for crust-mantle evolution. Earth Planet. Sci. Lett. 87, 59-72.

WoOden J. L., Stacey J. S. Howard K. A., DoE B. R., and Miller D. M. (1988) Pb isotopic evidence for the formation of Proterozoic crust in the southwestern United States. In Metamorphism and Crustal Evolution of the Western United States (ed. W. G. ERNST), Rubey Vol. VII, pp. 68-86. Prentice Hall.

ZARTMAN R. A. (1974) Lead isotopic provinces in the Cordillera of the western United States and their geologic significance. Ecom Gerl. 69, 792-805.

ZarTMAn R. A. and DOE B. R. (1981) Plumbotectonics--the model. Tectonophys. 75, 135-162.

ZARTMAN R. A. and WASSERBURG G. J. (1969) The isotopic composition of $\mathrm{Pb}$ in potassium feldspars from some 1.0 b.y. North American igneous rocks. Goochim. Cosmochim. fcta 33, 901942.

ZINDIER A. and HART S. R. (1986) Chemical geodynamics. Ann Re'. Earth Planet. Sci. 14, 493-571. 